\title{
Tadeusz KOPYS
}

Uniwersytet Jagielloński, Kraków

\section{Polityka obrony mniejszości narodowych i polityka zagraniczna Węgier. Casus Karty Węgra w stosunkach węgiersko-słowackich i węgiersko-rumuńskich}

Powiększająca się Unia Europejska regulowała kwestie narodowościo- we według wzorców demokracji i praw człowieka od wieków wypracowanych w Zachodniej Europie. Rozszerzanie się Unii na wschód, a jeszcze wcześniej wprowadzenie traktatu z Schengen zbiegło się w czasie z pojawieniem się w Europie Środkowej problemów natury narodowościowej, jak też i innych, dotyczących obywatelstwa. Już od 1990 roku sprawy te regulowały postanowienia Europejskiego Trybunały Sprawiedliwości (sprawa C-369/90 z 7 lipca 1990 roku) w sprawie Michelettiego $^{1}$. Po 1989 roku kilka państw Unii Europejskiej oraz Europy Środkowej uchwaliło ustawy, których założenia częściowo pokrywały się z postanowieniami, w jakie parlament węgierski w 2001 (tzw. Karta Węgra) roku pragnął wyposażyć obywateli węgierskich zamieszkujących kraje sąsiednie. W Europie Zachodniej (ale także w krajach Europy Wschodniej) stosowano wcześniej specjalne przywileje wobec obywateli określonych państw: Portugalia będąca członkiem UE zniosła obowiązek wizowy dla obywateli Brazylii. Rumunia wprowadziła szereg przywilejów dla mieszkańców pochodzenia rumuńskiego w Mołdowie. Rosja wprowadziła przywileje dla obywateli estońskich pochodzenia rosyjskiego. Wśród sąsiadów Węgier ustawy podobne do Karty Węgra uchwaliły parlamenty Słowacji i Rumunii.

1 W rozstrzygnięciu tej sprawy przyznano, że każde państwo ma prawo do naturalizacji innych obywateli, a państwa trzecie są zobowiązane fakt ten uznać, jeśli tylko istnieją ,autentyczne więzi” łączące państwo dokonujące naturalizacji a wspomnianą osobą. Jeśli ich brak naturalizację taką można podważyć. Zob. szerzej: H. Küpper, From the Status Law to Initiative for 'Dual Citizenship'. Aspects of Domestic Hungarian and International Law, Materiały z konferencji naukowej, która miała miejsce w Budapeszcie w dniach 14-16 października 2004 roku. 
Już od momentu upadku reżimu Janosa Kadara jednym z ważniejszych fundamentów węgierskiej polityki zagranicznej była problematyka obrony mniejszości węgierskiej w krajach ościennych. Kulminacją tych zabiegów było uchwalenie w 2001 roku przez parlament Węgier ustawy o ludności węgierskiej żyjącej poza granicami kraju. Jednak już od początku lat 90-tych rządy węgierskie i opinia publiczna w różnorodny sposób nagłaśniały sprawę mniejszości węgierskiej. Opieka nad rodakami w krajach sąsiednich jest konstytucyjne zagwarantowana (w § 6 ustęp 3 ustawy z 1989 roku) jako jeden z ważnych aspektów polityki zagranicznej tego państwa. Rząd Józsefa Antalla (1990-1994) zabiegał o interesy Węgrów w krajach sąsiednich $\mathrm{w}$ ramach istniejących organizacji, a ponadto koncentrował uwagę na integracji z Unią Europejską i przyjaznych stosunkach w tymi państwami, w których zamieszkiwała mniejszość węgierską starając się wypracować względną równowagę na tym polu. Polityka ta zmierzała do wypracowania środkowoeuropejskiego modelu w traktowaniu spraw narodowościowych. Rząd w Budapeszcie kierował się także założeniem, aby żadnych decyzji dotyczących rodaków nie podejmować bez ich zgody i ich zaangażowania w publicznej debacie. Ponadto rząd Antalla starał się wypracować projekt autonomii dla wspomnianej ludności². Kolejny, socjalistyczny tym razem rząd Gyuli Horna (1994-1998) podchodził pragmatycznie do tematyki mniejszości. Opiekę nad rodakami postanowiono zagwarantować traktatami z państwami sąsiednimi. Owocem tych działań były traktaty z Rumunią i Słowacją. Drugim elementem węgierskiej polityki zagranicznej $\mathrm{w}$ tym czasie były starania o integrację z Unią Europejską i one właśnie implikowały potrzebę utrzymywania dobrosąsiedzkich stosunków z sąsiadami. Trzecia płaszczyzna tejże polityki dotyczyła budowania wśród Węgrów w państwach sąsiednich zrębów społeczeństwa obywatelskiego i wzmocnienia infrastruktury ekonomicznej w tych środowiskach ${ }^{3}$. Tak powstała organizacja Új kézfogás, której celem było wspieranie lokalnych struktur po obydwu stronach granicy. Słabością tej polityki było to, że lokalne inicjatywy nie współgrały z założeniami kreowanymi w Budapeszcie.

Węgierski minister spraw zagranicznych Géza Jeszenszky odbył podróż do Beregova na Zakarpaciu w dniu 4 kwietnia 1992 roku. Spotkał się

2 L. Szarka, Határon túli magyar autonómia koncepciók, Budapeszt 2003, s. $34-40$.

3 L. Lábody, A határon túli magyarság és a gazdasági együttmüködés, „Társadalmi Szemle" 1993, nr 11, s. 67-71. 
tam z Anatolym Zlenką szefem ukraińskiego MSZ, a rozmowy pomiędzy nimi upłynęły pod znakiem przygotowań do późniejszej wizyty ukraińskiego premiera Witolda Fokina w maju 1992 roku. Węgierski premier József Antal złożył deklarację, że Ukraina jest dla Węgier wyjątkowym partnerem politycznym spośród Wspólnoty Niepodległych Państw. Ukraina jednak stanowczo była przeciwna powoływaniu na Zakarpaciu regionu autonomicznego dla tamtejszych Węgrów. Strona ukraińska odrzuciła takie plany, umożliwiając jednocześnie powołanie samorządu w tej części kraju. Dużym krokiem w regulacji spraw mniejszości była wizyta prezydenta Krawczuka na Węgrzech pod koniec lutego 1993 roku. Jej owocem było podpisanie porozumień regulujących kwestie przekraczania granicy, a także wycofywania nielegalnych imigrantów.

W 1992 roku Węgry podpisały z Ukrainą układ o dobrosąsiedzkich stosunkach, który posłużył w przyszłości jako wzór do podobnych traktatów z Rumunią i Słowacją. W tym samym roku obydwa państwa podpisały Deklarację o Ochronie Mniejszości Narodowych, zaś w 1993 roku węgierski parlament uchwalił ustawę o ochronie mniejszości narodowych, wprowadzając dwojaką autonomię: personalną i kulturalną.

Wreszcie w okresie rządów Viktora Orbána (1998-2002) udało się, wykorzystując korzystną sytuację polityczną kraju (wyraźny wzrost ekonomiczny i silna centro-prawicowa koalicja) i na arenie międzynarodowej (przystapienie do NATO i otwarcie bazy wojskowej USA w Taszár) wystąpić z ideą budowania wspólnoty z rodakami żyjącymi w sąsiednich państwach. Rząd węgierski wystąpił jako inicjator szeregu przedsięwzięć także starając się przekształcić Budapeszt w lokalne centrum finansowe i popierając aktywność firm węgierskich w Europie Środkowej. Ponadto FIDESZ będący filarem rządu Orbána dążył do skupienia wokół siebie prawicowego elektoratu i stąd wynikało jego dążenie do wzmocnienia węgiersko-węgierskich (w znaczeniu: Węgrów żyjących w krajach sukcesyjnych) stosunków. Ta aktywność doprowadziła do powstania Autonómia Tanács (Rada Autonomiczna) oraz pierwszych oficjalnych rozmów polityków węgierskich z kraju i zza granicy.

Wybory parlamentarne w 2002 roku przyniosły zwycięstwo lewicy na czele z Péterem Medgyessym. Jego rządy charakteryzowały się stopniowym odejściem od „ostrego" ujęcia ustawy z 2001 roku. Priorytetem było członkostwo w Unii Europejskiej, a z dawnego ujęcia Karty Węgra pozostała jedynie chęć powołania czegoś w rodzaju Commonwealth węgierskiego obszaru językowego. Efektem tego była deklaracja z Esztergom z maja 2004 roku (declaration). Ustawa z 2001 roku miała zapobiec 
także nowej sytuacji, jaka miała powstać po przystąpieniu Węgier do traktatu z Schengen. Karta Węgra miała za zadanie rozszerzyć szereg przywilejów, jakich byliby pozbawieni Węgrzy w krajach sąsiednich (poza Austria) po rozszerzeniu Unii Europejskiej. Jeszcze w połowie lat 90-tych bowiem wiele wskazywało, że Słowacja pod rządami izolacjonisty Vladimira Mečiara oraz Rumunia schlebiająca rządom autorytarnym mogą na długo pozostawać poza Unią Europejską i strefą Schengen.

Jak już wspomniano ustawa o obywatelstwie z 2001 roku była wynikiem trwającej od początku lat 90-tych debaty na węgierskiej scenie politycznej. Jej kumulacją była dyskusja w latach 1996-1998 na temat autonomii dla ludności węgierskiej w krajach sąsiednich. W tym czasie podjęto na Węgrzech próbę zinstytucjonalizowania relacji Węgier z ludnością madziarską w krajach sąsiednich. Najwięcej uwagi skupił projekt Miklósa Duraya, który reprezentował Magyarok Világszövetsége (Światowa Organizacja Węgrów). Duray wystąpił z koncepcją tzw. külső állampolgárság (obywatelstwa zewnętrznego), natomiast w toku debaty przed przyjęciem ustawy pojawiły się idee ,narodowej reintegracji” i ,narodu kontraktowego"4.

Omawiana ustawa z 2001 roku stanowiła, że Węgrzy bez względu na kraj, w jakim żyją wchodzą w skład jednolitego narodu węgierskiego (egységes magyar nemzet) ${ }^{5}$. Węgierska legislacja była próbą wprowadzenia w życie etnokulturowej definicji narodu w Europie Środkowej w przeciwieństwie do często nadużywanej etnopolitycznej definicji. Przede wszystkim należy podkreślić, że Węgrzy nie dążyli do wytworzenia wspólnoty narodowej ze stolicą w Budapeszcie, lecz przeciwnie nowego rozumienia narodu jako całego kompleksu spraw łączących różne wspólnoty poza granicami Węgier oraz Budapesztu. Zresztą owe wspólnoty - szczególnie w Rumunii i na Słowacji - stają się powoli niezależnymi centrami węgierskiego życia narodowego (przewodniczący Romaniái Magyar Demokrátikus Szövetség Béla Markó był jednym z ważniejszych polityków w Bukareszcie, a jego partia wchodziła w skład koalicji rządzącej). Postanowienia Karty Węgra weszły w życie w styczniu 2002 roku pod nazwą 1.2001.èvi LXII törvény a szomszédos államokban èlö magyarkoról (Ustawa o Ludności Węgierskiej Żyjącej w Sąsiednich Państwach nr LXII

4 I. Borbély, A magyar állampolgárság alanyi jogának kiterjesztése inden magyarra, „Magyar Kisebbségg” 1999, nr 2-3, s. 13-17.

5 Słowo egységes oznacza w języku węgierskim ,jednolity”. Użyto go prawdopodobnie celowo, aby nie drażnić rządów sąsiednich państw, które często używają na określenie swoich państw sformułowania „unitarny”. 
z 2001 roku). Ustawa nadawała obywatelom narodowości węgierskiej żyjącym w sąsiednich państwach szereg różnorodnych praw przysługujących obywatelom Republiki Węgierskiej. Dotyczyła ona Madziarów na Ukrainie, Słowacji, w Rumunii i byłej Jugosławii. Wyłączono z jej zakresu działania Węgrów austriackich. Węgrzy z krajów sąsiednich mogli kształcić się na węgierskich uczelniach, podejmować także pracę, a nawet korzystać z bezpłatnej opieki zdrowotnej na Węgrzech. Według badaczy węgierskich wspomniana ustawa realizowała etniczno-kulturową oraz terytorialną definicję narodu. Ustawa z 2001 roku przykładała wielką wagę do znajomości języka węgierskiego. Poprzez wyznaczenie tak ważnej roli językowi jako czynnikowi tożsamości narodowej wiązano ustawę z nacjonalizmem i asymilacją ludności niewegierskiej w XIX wieku ${ }^{6}$.

W okresie prac rządu Orbána narosły kolejne nieporozumienia w sprawie Karty Węgra. Słowacja zgłosiła propozycję, aby węgierską ustawę przeanalizowało Zgromadzenie Parlamentarne Rady Europy. Konflikt słowacko-węgierski osiagną̧ apogeum, kiedy Viktor Orbán poparł stanowisko jednego z niemieckich deputowanych do Parlamentu Europejskiego krytykującego tzw. dekrety Benesza, twierdząc, iż takie ustawodawstwo popierało zasadę zbiorowej odpowiedzialności. Media na Słowacji podniosły głos oskarżając premiera Węgier, że pragnie on zmusić Republikę Czeską i Słowację, aby te unieważniły dekrety przed przystąpieniem wspomnianych krajów do Unii Europejskiej. Napięcie pomiędzy państwami Środkowej Europy doszło do takiego stanu, że premier Dziurinda odwołał swój udział w konsultacjach głów „państw wyszehradzkich” w węgierskim Keszthely w marcu 2002 roku. Także premier Republiki Czeskiej Miloš Zeman po konsultacjach z Dziurindą odwołał swój udział we wspomnianym szczycie szefów rządów. W przypadku stosunków słowacko-węgierskich strona węgierska długo protestowała przeciwko członkostwu Słowacji w Radzie Europy z powodu oskarżenia o łamanie przez Bratysławę praw mniejszości węgierskiej w tym kraju ${ }^{7}$. W połowie maja 1993 roku węgierscy posłowie w słowackim parlamencie przedłożyli listę warunków, które Rada Europy nakazała wypełnić Słowakom przed ich przystapieniem do Rady. Propozycja nie została nigdy przegło-

6 Z. Kántor, A magyar nemzetpolitka és státustörvény, w: Státustörvény. Dokumentumok, tanulmányok, publicisztika, pod red. Z. Kántora, Budapeszt 2002, s. 201.

7 Niewyjaśniona była także sprawa budowy stopnia wodnego na Dunaju w rejonie miejscowości Nagymaros-Gabčikovo. Jej budowa spowodowałaby zalanie wodami rzeki terenów na Węgrzech położonych poniżej jej poziomu. 
sowana przez parlament Słowacji i stała się powodem oskarżeń przywódców mniejszości węgierskiej za ich „blokowanie” członkostwa Słowacji w Radzie Europy. W dniu 30 czerwca 1993 roku Słowacja pomimo oficjalnego protestu Węgier została członkiem Rady Europy. Decyzja ta spowodowała liczne manifestacje i protesty w południowej Słowacji, których uczestnicy żądali wprowadzenia dwujęzycznych nazw miejscowości. Dopiero rok później słowacki parlament uchwalił ustawę, na mocy której 590 miast i wiosek w południowej części kraju mogły używać nazw w dwu językach.

W pierwszej połowie kwietnia 2001 roku podczas wizyty premiera Słowacji Mikuláša Dziurindy w Budapeszcie, słowacki gość stwierdził, że uchwalenie ustawy mogłoby ,zepsuć atmosferę współpracy” pomiędzy Republiką Słowacji i Węgrami. Wyraził także wolę konsultacji na temat ustawy z rządem węgierskim. Ponownie w lutym 2002 roku Słowacka Rada Narodowa uchwaliła rezolucję, w której wzywała parlament węgierski do modyfikacji Karty Węgra, zarzucając ustawie niezgodność z normami europejskimi i słowackim prawodawstwem. Ustalenie spornych kwestii nastąpiło dopiero pod koniec 2003 roku. Podpisano wówczas porozumienie dwustronne o poszanowaniu praw mniejszości. Dyskusja na temat Karty Węgra rozgorzała na Słowacji w październiku 2001 roku, a więc mniej więcej na dwa miesiące przed wejściem ustawy w życie. Za negocjacje ze stroną węgierską odpowiedzialny był początkowo sekretarz stanu w słowackim MSZ Jaroslav Chlebo. Od początku też nastąpił swoisty podział opinii na arenie politycznej Słowacji w stosunku do Karty Węgra. Chlebo reprezentował „stanowisko twarde”, podczas gdy minister Kukan podejście bardziej umiarkowane. W dniu 31 października 2001 roku Jaroslav Chlebo spotkał się w Bratysławie z wiceprzewodniczącym Határon Túli Magyarok Hivatal (HTMH - Urząd ds. Węgrów Poza Granicami) ${ }^{8}$ Tiborem Szabó, podczas którego uzgodniono sposób i tryb wydawania paszportów. Pierwsze spotkanie na poziomie rządów odbyło się także w Bratysławie 22 listopada 2001 roku. Wziął w nim udział Chlebo i sekretarz węgierskiego MSZ Zsolt Németh. Ustalono wówczas trzy spawy. Po pierwsze Budapeszt zobowiązał się wysłać na Słowację rozporządze-

${ }^{8}$ Urząd ten działa przy węgierskim rządzie i nadzorowany jest przez urzędnika w randze podsekretarza z kancelarii premiera. Urząd ds. Węgrów Poza Granicami posiada też uprawnienia do kształtowania polityki zagranicznej Republiki Węgierskiej w dziedzinie stosunków narodowościowych i ochrony mniejszości węgierskiej w krajach sąsiednich. 
nia wykonawcze do ustawy, które nie zostały przyjęte w Bratysławie. Po drugie strona słowacka zobowiązała się przygotować listę zarzutów wobec ustawy, co ostatecznie miało miejsce, ale z 5-miesięcznym opóźnieniem w połowie kwietnia 2002 roku. Po trzecie ustalono powołać wspólną węgiersko-słowacką grupę specjalistów, która miała zająć się zgodnością Karty Węgra z normami europejskimi (komisja ta nie została nigdy powołana). Wydaje się, że strona słowacka wykazała mniej dobrej woli w sprawie porozumienia. Kiedy 9 stycznia 2002 roku zastępca sekretarza w węgierskim MSZ Csaba Lőrincz złożył wizytę w Bratysławie i zaproponował podpisanie ugody w sprawie Karty Węgra, podobnej do tej, jaką kilka tygodni wcześniej Węgry podpisały z Rumunią, strona słowacka nie zareagowała. Ponadto Csaba Lőrincz zaproponował, aby specjalna słowacka fundacja nadzorowała przyznawanie stypendiów dla słowackich Węgrów. Druga propozycja węgierskiego dyplomaty związana była z powołaniem Mieszanego Komitetu Słowacko-Węgierskiego, którego zadaniem miałoby być wprowadzenie ustawy w życie. Strona słowacka żądała jednak, aby funkcjonowanie takiego komitetu formułowała odrębna ustawa. Całość problemu została zamknięta poprzez enigmatyczne oświadczenie ministra Eduarda Kukana na konferencji prasowej w dniu 15 stycznia 2002 roku, kiedy oświadczył on, że zaistniały problem nie dotyczy strony słowackiej i rozwiązania sporu należy szukać na Węgrzech ${ }^{9}$.

Do początku stycznia 2002 roku Dziurinda nie zabierał głosu w omawianej kwestii, a pierwsze bezpośrednie rozmowy miały miejsce 22 listopada 2001 roku z udziałem sekretarzy stanu obydwu ministerstw spraw zagranicznych. Pod koniec listopada 2001 roku komisja spraw zagranicznych parlamentu Słowacji wydała oświadczenie przeciw Karcie Węgra, a od początku stycznia uczyniły to główne partie słowackiej sceny politycznej.

Pomysł finansowania wyższych szkół z wydziałami w węgierskim języku nauczania w Rumunii spowodował protest w Bukareszcie. W maju 2001 roku premier Rumunii Adrian Nastase - kiedy na Węgrzech jeszcze debatowano nad kształtem ustawy - oświadczył, że jest ona nie do przyjęcia oraz dopóki nie dojdzie na jej temat do publicznej debaty w Rumunii i nie wyjaśni się niektórych jej aspektów sprzecznych z wewnętrznymi regulowaniami i zasadami konstytucyjnymi obowiązującymi w Rumunii ${ }^{10}$.

9 A magyar státustörvény fogadtatása és alkalmazása a Szlovák Köztársaságban, dokument dostępny na stornie Center for Legal Analyses: www.cla.sk.

10 S. Z. Troie, The Hungarian Status Law In Romania. Anatomy of Inter-National Dispute, „Slovo” vol. 16, nr 1, Spring 2004, s. 23-25. 
Niedługo po wystapieniu Nastase prezydent Ion Iliescu zagroził odrzuceniem podpisanego w 1996 roku traktatu węgiersko-rumuńskiego. Koła skrajnie nacjonalistyczne w Rumunii skupione wokół przywódcy Partii Wielkiej Rumunii Corneliu Vadima Tudora porównywały przyjęcie Karty Węgra do wypowiedzenia wojny przez Budapeszt. Tudor zażądał, aby granica węgiersko-rumuńska została zamknięta, a armia rumuńska postawiona w stan gotowości na wypadek zaistnienia kryzysowej sytuacji. Prasa rumuńska bardzo szybko przyjęła ton oskarżyciela obarczając stronę węgierską o ,popieranie irredentyzmu” i „dyskryminację". Oskarżenia te szybko podjęte zostały przez administrację lokalną w Siedmiogrodzie. Burmistrz miasta Cluj-Napoca Gheorghe Funar stwierdził wręcz: „Prawo to jest częścią prób [podjętych przez Węgry] mających na celu odzyskanie starych terytoriów" ${ }^{\prime 1}$. Przyczyniło się to do tego, że rumuńska opinia publiczna ostro sprzeciwiała się wprowadzeniu tej ustawy na terytorium Rumunii. Rumunia i Słowacja blokowały negocjacje Węgier z Unią Europejską, co spowodowało także reakcje w samej Brukseli. Reakcją rządu w Bukareszcie było porozumienie z Węgrami z grudnia 2001 roku, w którym na obywateli rumuńskich rozszerzono prawo podejmowania pracy na Węgrzech ${ }^{12}$.

Strona węgierska broniła swojego stanowiska. Dał temu wyraz premier Viktor Orbán w dniu 28 czerwca 2001 roku w wywiadzie dla Radia Kossuth, który w wypowiedzi tej stwierdził, że Karta Węgra nie narusza ustawodawstwa Unii Europejskiej. Według niego było wręcz przeciwnie, węgierska ustawa była uchwalona przy pełnym poszanowaniu norm prawa europejskiego. Orbán podkreślał, że idea Europy jest zbudowana na przywiązaniu do obywatelstwa i tożsamości narodowej. Z kolei prezydent Iliescu w wywiadzie dla telewizji węgierskiej w dniu 26 maja 2001 roku w bardzo delikatnym tonie podkreślił, że w wielu punktach ustawa z 2001 roku wychodzi przeciw idei tożsamości europejskiej. W tym czasie premier Nastase w czasie telekonferencji podkreślił, że „... premier Orbán daje nam lekcje na temat wartości europejskich, podczas gdy jego antyeuropejska postawa jest oczywista"13. Także w Unii Europejskiej po-

11 A. Purvis, The Empire Strikes Back, „Time”, 25 luty 2002.

12 B. Fowler, Fuzzing Citizenship, Nationalising Political Space: A Framework for Interpreting the Hungarian "Status Law” as a New Form on Kin-State Policy in Central and Eastern Europe, w: One Europe or Several?, Programme Working Paper 40/02, Brighton 2002.

13 „Romania Libera”, 23 czerwca 2001. 
jawiły się głosy sprzeciwu. W kwietniu 2001 roku ambasador Ukrainy w Budapeszcie wyraził nadzieję, że deputowani węgierskiego parlamentu wezmą pod uwagę opinie i reakcje, jakie wywołały w sąsiednich krajach przygotowania do ustawy.

Bez wątpienia najbardziej pozytywne opinie dotyczące węgierskiej ustawy wyrażano w środowiskach mniejszości węgierskiej w sąsiednich krajach. Szef Vajdasági Magyarok Szövetsége (Związek Węgrów w Wojwodinie), a także zastępca premiera Serbii w jednej osobie József Kasza projekt ustawy ocenił jako pozytywną zapowiedź, polityczny zwrot, pierwszy od 1920 roku tj. od czasów traktatu w Trianon, kiedy to kraj utracił 2/3 swojego historycznego terytorium.

Przystąpienie Węgier do Unii Europejskiej w maju 2004 roku stworzyło lepsze możliwości dla Węgier, którzy mogą od tego czasu traktować Unię Europejską jako instrument w procesie obrony rodaków żyjących w sąsiednich państwach. Grupa 24 węgierskich eurodeputowanych jest jednak za słabą reprezentacją wśród 732 posłów Parlamentu Europejskiego. Zdaniem reprezentantów centroprawicowego Fideszu Etelki Barsiné Pataky i Istvána Pálfi'ego oraz posła SZDSZ Istvána Szent-Iványi’ego węgierscy deputowani powinni stworzyć jednolitą grupę popierającą szeroko rozumiane interesy mniejszości węgierskiej w krajach sąsiednich. Politycy węgierscy posunęli się nawet do akceptacji opinii kanclerza Austrii Wolfganga Schlüssela, który był zdania, że przyjęcie Rumunii i Bułgarii do Unii powinno nastąpić dopiero w 2009 roku. Pálfi posunął się nawet do przesunięcia daty ewentualnej akcesji Rumunii do 2014 roku.

W 2003 roku węgierski minister do spraw integracji z Unią Europejską Endre Juhász wspomniał, że Węgry powinny blokować rozmowy Rumunii na temat jej przyszłego członkostwa w strukturach EU. W ten sposób doszło do przyspieszenia rozmów Rumunii z Brukselą, aby najważniejsze tematy zamknąć jeszcze przed majem 2004 tzn. przed spodziewanym członkostwem Węgier. Jednocześnie tak Unia, jak i Rumunia odrzuciły zaproponowane przez ministra spraw zagranicznych Węgier László Kovácsa rozmowy o poszerzeniu Unii o Rumunię i Bułgarię. Miały one odbyć się 21 czerwca 2003 roku w Budapeszcie, natomiast tego samego dnia w Brukseli rozmowy na identyczny temat miał zainicjować minister Juhász. Minister Juhász stwierdził, po fiasku swojej propozycji, że stronie węgierskiej nie chodziło o obecność przy stole negocjacyjnym Rumunii, ale jedynie o informację w jakim stopniu rozmowy są zaawansowane. Był zmuszony dodać, że Węgry są zainteresowane utrzymaniem z Rumunią - z którą posiadają najdłuższą granicę - poprawnych stosun- 
ków. W tym czasie rzecznik węgierskiego MSZ Tamas Tóth zapewnił, że w interesie Węgier leży, aby Rumunia została członkiem struktur europejskich, dodając przy tym, że udział Węgier w rozmowach Bułgarii i Rumunii z Brukselą jest o tyle uzasadniony, gdyż wiele istniejących w tych trzech państwach problemów łączy je ze sobą. Odrzucenie węgierskiej propozycji wywołało nastroje tryumfu w Bukareszcie. Tamtejsza prasa donosiła wręcz, że odkąd Węgry zostały pokonane w bitwie o tzw. Kartę Węgra nie przestały myśleć o słodkiej zemście.

Jeszcze przed oficjalnym uchwaleniem ustawy przez węgierski parlament prezydent Iliescu odwiedził dwa powiaty w Siedmiogrodzie Harghita i Covasna, gdzie większość stanowili Węgrzy. Próbował w ten sposób poznać nastroje panujące wśród miejscowej ludności.

Uchwalenie ustawy wywołało w krajach sąsiednich falę niezadowolenia z powodu ograniczenia dostępu do węgierskiego rynku pracy dla obywateli Rumunii, Słowacji oraz Serbii i Czarnogóry. Oznaki dezaprobaty nadchodziły także z organizacji międzynarodowych i Unii Europejskiej. Na spotkaniu z reprezentantami Węgier w połowie lipca 2001 roku komisarz ds. rozszerzenia G. Verheugen oznajmił: „Węgry od wielu lat urzeczywistniały idee współpracy w regionie występując jako przykład dla innych państw. Zatem [...] nie widzę powodów do niepokoju z powodu zastosowania [wprowadzenia w życie - przyp. T. K.] Karty Węgra"14. Reakcje te miały jednak niewielki wpływ na podejście rządu węgierskiego do tego zagadnienia, ponieważ Budapeszt uznawał ustawę za narzędzie poprawiające jakość kontaktów rodaków z krajem. Opinie innych państw na temat ustawy nie były już tak pochlebne. Ambasador Belgii (sprawowała ona w tym czasie prezydencję w Unii Europejskiej) w Budapeszcie Fernand van Brusselen w wywiadzie udzielonym tego samego dnia podkreślił, że Węgry podkopały stabilizacyjną rolę w regionie, jaką dotychczas w nim spełniały. Pod koniec października 2001 roku Venice Commission $^{15}$, która wcześniej zajęła się legalnością postanowień Karty

${ }^{14}$ EU-Hungary Hold Association Meeting, Hungarian News Agency (MTI), 18 lipca 2001.

${ }_{15}$ Instytucja powołana w 1990 roku jako ciało doradcze Rady Europy. Jego pełna nazwa brzmi European Commission for Democracy through Law. Zasadniczym celem komisji jest zapobieganie i rozwiązywanie konfliktów spornych, a w art. 2 jej statutu założyciele stanowią, że w jej skład wchodzą eksperci, którzy zdobyli doświadczenie w rozwiązywaniu konfliktów lub są wybitnymi znawcami stosunków międzynarodowych i prawa. Wieloletnim reprezentantem Polski w Komisji była Hanna Suchocka. 
Węgra nie wyeksponowała wyraźnego stanowiska wobec węgierskiej ustawy. Z jednej strony uznano za zasadną opiekę (na płaszczyźnie kulturalnej i oświatowej), jaką Węgry otoczyły rodaków w krajach sąsiednich. $\mathrm{Z}$ drugiej strony potępiono fakt, że Węgry uchwaliły ustawę bez uprzednich konsultacji z zainteresowanymi państwami, a jednocześnie nadały organizacjom mniejszości w Rumunii rangę politycznych przedstawicielstw. Generalnie jednak nie potępiając całkowicie węgierskiej propozycji prawnej Venice Commission opowiedziała się raczej za rumuńską definicją równości niż europejskim ujęciem spraw narodowych w rozumieniu ustawy z 2001 roku. Orbán, rząd węgierski i niektórzy obserwatorzy w Unii Europejskiej nie uważali Karty Węgra za ustawę odstająca w swoich założeniach od innych tego typu ustaw w Europie Środkowej, ale także w samej Rumunii. O słuszności ustawy przekonywał węgierski minister spraw zagranicznych János Martonyi w wypowiedzi dla jednego z czołowych rumuńskich dzienników „Adevărul” twierdząc, że ustawa w żadnym stopniu nie stoi w sprzeczności z wartościami europejskimi.

Strona rumuńska, powołując się na samą ideę Europy, odrzuciła możliwość wprowadzenia w życie nowego prawa na terytorium Rumunii. Obydwa rządy niezadowolone z zaistniałej sytuacji zwróciły się o pośrednictwo do instytucji unijnych i międzynarodowych. Politycy rumuńscy zwrócili się z prośbą o rozstrzygnięcie sporu do przewodniczącego Komisji Europejskiej Romano Prodiego, komisarza Güntera Verheugena i komisarza Chrisophera Pattena. W tym czasie węgierscy politycy próbowali zneutralizować akcję Rumunii w Radzie Europy. W lipcu 2001 roku Rolf Ekéus, wysoki komisarz ds. mniejszości narodowych przy OBWE postanowił odwiedzić Budapeszt i Bukareszt, aby naocznie poznać podłoże sporu. Podobnie ministrowie Năstase i Martonyi oficjalnie zwrócili się do jednej z komisji przy Radzie Europy, aby ta rozstrzygnęła sprawę. Rozwiązania sytuacji spornej przyszło szukać nie za pośrednictwem międzynarodowych rozjemców, ale w stosunkach bilateralnych. Pierwszym pomocnym rozwiązaniem była decyzja Venice Commission z października 2001 roku. Raport komisarza OBWE jak też inne raporty próbujące wyjaśnić sens Karty Węgra w sposób naukowy nie przeważyły ostatecznie o racji rządu węgierskiego ani też protestujących państw sąsiednich ${ }^{16}$. Rolf Ekéus w swoim raporcie zawarł bardzo oczywisty dla środkowoeu-

16 R. Ekéus, Sovereignity, Responsibility and National Minorities: Statement by OSCE Minorities Commissioner, OSCE Press Release, 26 October 2001. 
ropejskich realiów wniosek, w którym stwierdził, że granice państwowe często nie pokrywają się z przynależnością poszczególnych narodów do państw. Jednakże nie podważył prawa rządu węgierskiego do opieki nad ludnością węgierskojęzyczną. Podobną opinię wygłosił Erik Jürgens profesor prawa, który w swoim raporcie posługiwał się jedynie definicją narodu politycznego występującą jednak częściej na Zachodzie nie w Europie Środkowej. Kilka wersji raportu Jürgensa funkcjonowało w organizacjach międzynarodowych, a w końcu Zgromadzenie Parlamentarne Rady Europy zaakceptowało go pod koniec czerwca 2005 roku.

Rolf Ekéus uczestniczył także w rozmowach słowacko-węgierskich w dniu 25 stycznia 2002 roku. Brali w nich udział także słowaccy ministrowie Edvard Kukan i Pál Csáky (minister ds. praw człowieka w rządzie Słowacji, Węgier z pochodzenia). Wcześniej w połowie stycznia doszło do rozmów prezydenta Słowacji Rudolfa Schustera z premierem Dziurindą na temat Karty Węgra. Dziurinda stwierdził podczas niego, że nie zgodzi się na wprowadzenie w życie węgierskiej ustawy na terytorium Słowacji, jeśli ta miałaby podzielić społeczeństwo na tle narodowościowym. W tym czasie wśród partii politycznych na Słowacji nasiliły się negatywne opinie na temat ustawy. Słowacka Partia Narodowa w dniu 29 stycznia 2002 roku przedstawiła nawet projekt kontr-ustawy i zgłosiła projekt odebrania mandatu posłom słowackiego parlamentu, którzy złożyliby wniosek o węgierski dowód osobisty. Przywódca Ruchu na Rzecz Demokratycznej Słowacji Vladimir Mečiar wyraził także opinię, że wprowadzenie w życie ustawy mogłoby poważnie osłabić stosunki węgiersko-słowackie. Prawie identyczną deklarację wygłosił węgierski minister spraw zagranicznych László Kovács, który w maju 2002 roku w trakcie rokowań akcesyjnych Węgier stwierdził: „Nowy gabinet [węgierski] przewartościuje na nowo Kartę Węgra i w sporze ze Słowacją znajdzie takie rozwiązanie, które zachowując zasadnicze cele tejże ustawy będzie także możliwe do przyjęcia dla rządu słowackiego. W interesie Węgier i każdego innego państwa tego regionu leży, aby doprowadzić do normalizacji stosunków i usuwać powstałe napięcie"17. Do czasu kiedy obydwa rządy doszły do porozumienia, napięcie było tak duże, że na początku 2002 roku komisja immunitetowa parlamentu Słowacji rozważała pomysł odebrania mandatu poselskiego jednemu z bardziej znanych polityków węgierskich na Słowacji Miklósowi Duray’owi (deputowanemu do parla-

17 Új Szó, 24 maja 2002 r. 
mentu Słowacji), który w połowie czerwca przebywał w Budapeszcie, gdzie parlament węgierski uchwalał Kartę Węgra, a jednocześnie rzekomo „zaniedbywał” obowiązki deputowanego na Słowacji. Na początku lutego 2002 roku parlament Słowacji przegłosował uchylenie posłowi Duray’owi immunitetu (przy 112 głosach „za”, 2 wstrzymujących się i 15 głosach ,przeciw”"18). Plenum parlamentu zobowiązało, aby rząd w ciagu dwóch tygodni rozpoczął dochodzenie przeciw organizacji Szövetség Közös Célokért (Stowarzyszenie dla Wspólnych Celów, SzKC) ${ }^{19}$ (rząd słowacki zrealizował ten postulat w dniu 20 lutego 2002 roku). Dzień później tzn. 21 lutego 2002 roku doszło do kolejnego skandalu, kiedy komisja immunitetowa parlamentu Słowacji przerwała dochodzenie przeciwko Duray'owi, a także przerwała podobne dochodzenie wszczęte przeciwko Béli Bugárowi. Marszałek sejmu słowackiego wezwał jednocześnie Bugára, do tego, aby ten zrzekł się mandatu poselskiego.

Wydaje się, że Słowacja od początku zaistnienia sporu na temat Karty Węgra, dążyła do tego, aby na kwestii tej ugrać pewne ustępstwa na innych płaszczyznach. Słowacki minister Pál Csáky na konferencji prasowej w dniu 10 stycznia 2002 roku oznajmił, iż Węgry i Słowacja koniecznie powinny podpisać ugodę w omawianej sprawie. W tej sprawie rząd węgierski miałby poprzeć aspiracje słowackie do członkostwa w NATO. Ponadto biura, które węgierski ustawodawca planował zakładać w sąsiednich krajach miały mieć charakter jedynie informacyjny, a sam proces nadawania Węgrom dokumentów miałby odbywać się na terytorium Węgier $^{20}$. Ponadto słowacką scenę polityczną opanowała swoista histeria. Ján Slota szef nacjonalistycznej, Prawdziwej Słowackiej Partii Narodowej zgłosił wniosek w parlamencie, aby odwołać słowackiego ambasadora w Budapeszcie Stefana Markusa. Zewsząd oczekiwano lojalności polityków mniejszości węgierskiej wobec rządu w Bratysławie, jednakże jeden

18 Przeciw przyjęciu oświadczenia głosowali posłowie Magyar Koalició Part (Partia Węgierskiej Koalicji), której reprezentanci zasiadają w parlamencie słowackim.

19 Organizacja, która zajmowała się m.in. zakładaniem biur na terenie Słowacji, w których obywatele pochodzenia węgierskiego mogli składać wnioski o przyznanie paszportu przynależności do narodu węgierskiego. Powstała ona kilka tygodni po wejściu w życie Karty Węgra, a więc na przełomie stycznia-lutego 2002 roku. Do początku kwietnia 2002 roku z całego kraju, z istniejących biur SzKC napłynęło do ambasady węgierskiej 30,6 tys. wniosków o przyznanie paszportu ,„przynależności do narodu węgierskiego".

${ }^{20}$ A magyar státustörvény fogadtatása és alkalmazása..., op. cit. 
z liderów Partii Węgierskiej Koalicji Arpád Duka-Zólyomi oświadczył, że reprezentanci mniejszości węgierskiej nie będą brać udziału w dalszej debacie na temat Karty Węgra.

W listopadzie 2001 roku przedstawiono raport Komisji Europejskiej, w którym nie pozostawiono wątpliwości rządowi w Budapeszcie wskazując, że powinien on porozumieć się w tej kwestii z rządem rumuńskim. Czas naglił, albowiem ustawa miała wejść w życie 1 stycznia 2002 roku. Obie strony naciskane przez Unię Europejską podpisały w dniu 22 grudnia 2001 roku tzw. memorandum zrozumienia, w którym strona węgierska poczyniła szereg ustępstw dla obywateli Rumunii. Odtąd obywatele tego państwa - także niewęgierskiego pochodzenia - mogli pracować na Węgrzech przez dłuższy czas bez posiadania wizy pracowniczej. Rząd węgierski zgodził się także, że proces ubiegania się o przywileje kulturalno-oświatowe przez Węgrów rumuńskich może odbywać się na terytorium Węgier, natomiast na obszarze Rumunii tylko w węgierskich placówkach dyplomatycznych $^{21}$.

Należy dodać, że także 22 grudnia 2001 roku doszło do ugody ukraińsko-węgierskiej w sprawie Karty Węgra. Szef HTMH Tibor Szabó na konferencji prasowej oznajmił, iż ugoda polega na tym, że strona ukraińska zobowiązała się nadzorować jej egzekucję na terytorium Ukrainy. Podczas rozmów padła propozycja powołania do życia okręgu autonomicznego na Zakarpaciu dla mniejszości węgierskiej. Rząd w Kijowie nie poparł jednak tego postulatu, ponieważ nie był on w zgodzie z normami prawa ukraińskiego ${ }^{22}$.

Zanim Karta Węgra została uchwalona przez parlament w Budapeszcie spowodowała także wewnętrzne przemiany na scenie politycznej Rumunii. Rządząca wówczas w Rumunii koalicja liberałów i socjaldemokratów w kwietniu 2001 roku, aby uchwalić budżet na ten rok związała się z Demokratycznym Związkiem Węgrów w Rumunii (DZWR). Związanie się z partią mniejszości węgierskiej spowodowało wzrost napięć w szeregach koalicji, a w dalszej konsekwencji jej rozpad w połowie maja 2001 roku. Także skrajnie nacjonalistyczna Partia Wielkiej Rumunii C. V. Tudora określiła socjaldemokratów jako klienta węgierskiej mniej-

${ }^{21}$ Memorandum of Understanding between the Government of the Republic of Hungary and the Government of Romania concerning the Law on Hungarians Living in Neighbouring Countries and Issues of Bilateral Co-operation, 22 December 2001.

${ }^{22}$ http://www.jogiforum.hu/hirek/3099. 
szości, a szef rumuńskich liberałów porównał partię Tudora i DZWR do środowiska o szowinistycznym zapleczu społecznym. Jako obrońcy rumuńskich wartości narodowych wystapili wówczas liberałowie, których lider Valeriu Stoica stwierdził: „Nie pragniemy w Europie nowego pangermanizmu ani panslawizmu kryjącego się w formie panmadziaryzmu. Socjaldemokraci stracili słuch i nie słyszą nadciągającego z Budapesztu nacjonalizmu". Socjaldemokratyczny rząd w Rumunii naraził się na krytykę ze wszystkich stron sceny politycznej za bratanie się z partią mniejszości węgierskiej, ale największy problem sprawili nacjonaliści Tudora oraz liberałowie. W związku z tym rząd premiera Năstase już pod koniec maja 2001 roku był zmuszony zagrozić stronie węgierskiej, że bez wcześniejszych negocjacji ustawa nie będzie miała szans stać się obowiązującym prawem na terytorium Rumunii.

W dniu 18 lutego 2002 roku - w piątą rocznicę podpisania w 1997 roku traktatu o przyjaźni pomiędzy Węgrami a Rumunią - Budapeszt i Bukareszt podpisały wspólną deklarację, która wraz z tzw. memorandum zrozumienia stała się podstawą do kolejnej wypracowanej w lipcu 2003 roku przez rząd węgierski poprawionej, nowej wersji Karty Węgra. We wspólnej deklaracji obydwie strony wyraziły satysfakcję z ,niespotykanego rozwoju" w stosunkach pomiędzy dwoma państwami od 1997 roku. Za ich podstawowy cel wyznaczono podejmowanie niezbędnych środków „,... aby zapewnić i utrzymać narodową, kulturalną i językową tożsamość mniejszości narodowych, a także możliwość ich funkcjonowania w dobrobycie, w miejscu ich zamieszkania"23.

Pierwsza próba zmiany Karty Węgra miała miejsce w maju 2002 roku właściwie tuż przed objęciem rządów przez Pétera Medgyessyego. Pierwszy projekt nowej ustawy opracowano w połowie października tego samego roku. Węgierski MSZ konsultował się w kwestii modyfikacji ustawy z różnymi organizacjami węgierskimi. W lutym 2003 roku doszło do spotkania w Szatmárnémeti w Siedmiogrodzie na kongresie Romaniái Magyar Demokrátikus Szövetség, ale przy uczestnictwie delegata Węgrów słowackich Béli Bugára i wojwodińskich Józsefa Kaszy. Ustalono wówczas, że podstawowe założenia Karty Węgra nie ulegną zmianom. W październiku 2003 roku Węgry podpisały układy o ruchu bezwizo-

23 Joint Declaration on the Occasion of the 5th Anniversary of the Hungarian-Romanian Active Partnership, dostępne na stronie: http://www.kum.hu/Archivum/Korabbiszovivoc/2002/02/spok0218.htm. 
wym z Serbią, Czarnogórą i Ukrainą. W tym przypadku w układach tych nie wspominano już o pochodzeniu etnicznym osób, których ustawy te dotyczyły.

Na początku grudnia 2002 roku Günter Verheugen wysłał list do premiera Pétera Medgyessy'ego, w którym zwracał uwagę na przyjętą w kołach politycznych koncepcję narodu na Węgrzech traktowanego jako „naród węgierski jako całość”. Verheugen zwrócił uwagę na to, że takie ujęcie mogłoby sugerować dążenie rządu węgierskiego do zbudowania politycznych więzi łączących Węgrów z ich rodakami za granicami, a także sugerował użycie jak to określił „...bardziej kulturowo zorientowanej definicji” ${ }^{24}$. W wyniku krytyki międzynarodowych organizacji i wyborczego zwycięstwa socjaldemokracji węgierskiej w maju 2002 roku nowy rząd węgierski zdecydował się zmodyfikować Kartę Węgra. W ten sposób w nowej ustawie określenie „naród jako całość” zostało zastąpione przez frazę ,aby zagwarantować dobrobyt, tożsamość Węgrów żyjących poza granicami kraju”. W zmodyfikowanej ustawie znalazły się także zwroty wyrażające poparcie dla Madziarów poza granicami ojczyzny w ich staraniu do uczestnictwa w dziedzictwie kulturowym i narodowym.

Karta Węgra jest przykładem rozwiązania problemów narodowych i kwestii obywatelstwa w zmieniającej się rzeczywistości międzynarodowej po upadku muru berlińskiego i rozszerzającej się Unii Europejskiej. Poza dyskusją na Węgrzech, jak i wśród polityków Unii Europejskiej węgierska ustawa położyła nacisk na konieczność przedefiniowania pojęcia narodu czy wręcz zastąpienia pojęcia „naród” w znaczeniu politycznym przez status przynależności państwowej czy obywatelstwa. Karta Węgra i okoliczności jej uchwalenia, a potem wprowadzonych zmian dostarcza dowodów funkcjonowania polityki regionalnej w Europie Środkowej. Ponadto ustawa węgierska przyspieszyła prace nad podobnymi regulacjami w tym w Rzeczpospolitej Polskiej.

24 Zob. Z. Kántor, The Status Law Syndrome and regional/National Identity: Hungary, Hungarians in Romania and Romania, materiał dostępny na stronie internetowej kms1.isn.ethz.ch/.../Files/.../06_Kantor.pdf. 
The policy for protecting national minorities and Hungarian foreign policy. The case of the Hungarian Card in Hungarian-Slovak and Hungarian-Romanian relations

\section{Summary}

The Hungarian Card exemplifies how to solve nationality and citizenship issues in the transforming international reality after the collapse of the Berlin Wall and the expansion of the European Union. Regardless of the dispute in Hungary, as well as among EU politicians, Hungarian law has emphasized the need to redefine the concept of the nation, or even to substitute the political sense of this concept with the status of state membership or citizenship. The Hungarian Card, how it was passed and then successively amended, evidences that a regional policy is actually operating in Central Europe. Additionally, this Hungarian law has accelerated work on similar regulations in other countries, including Poland. 
